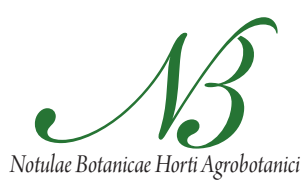

Cluj-Napoca

\title{
Molecular Characterization and Similarity Relationships among Flue-Cured Tobacco (Nicotiana tabacum L.) Genotypes Using Simple Sequence Repeat Markers
}

\author{
Soheila GHOLIZADEH ${ }^{1}$, Reza DARVISHZADEH ${ }^{1}$, Babak ABDOLLAHI MANDOULAKANI' \\ Iraj BERNOUSI', Seyed Reza ALAVI², Ardashir KHARABIAN MASOULEH ${ }^{3}$ \\ ${ }^{1}$ Urmia University, Department of Agronomy and Plant Breeding, Urmia, Iran; rdarvishzadeh@urmia.ac.ir ( ${ }^{*}$ corresponding author) \\ ${ }^{2}$ Urmia Tobacco Research Center, Department of Genetic, Urmia, Iran \\ ${ }^{3}$ Southern Cross University, Southern Cross Plant Science, Lismore NSW 2480, Australia
}

\begin{abstract}
Characterization of genetic diversity has long been a major goal in tobacco breeding programs. Information on genetic diversity is essential for a rational use of genetic resources. In the present study, the genetic variation among 72 flue-cured tobacco genotypes was evaluated using microsatellite markers (SSRs). A set of 104 alleles was generated at 30 SSR loci. The mean number of alleles per locus ( $n_{a}$ ) and the effective allele number $\left(n_{\mathrm{e}}\right)$ were 3.467 and 2.358 , respectively. The expected heterozygosity ranged from 0.29 to 0.75 with average of 0.54 . Several methods were used to construct the similarity matrices and dendrograms. The co-phenetic correlation coefficient, which is a measure of the correlation between the similarities represented on the dendrograms and the actual degree of similarity, was calculated for each dendrogram. Among the different methods, the highest value ( $\mathrm{r}=0.76368)$ was observed for the UPGMA created based on Jaccard's similarity coefficients. The genetic similarity among the tobacco genotypes calculated by using Jaccard's similarity coefficient ranged from 0.08 to 0.84 , suggesting the presence of high molecular genetic variability among the studied tobacco genotypes. Based on UPGMA clustering method all studied flue-cured tobacco genotypes, except for 'Glustinusa Rasht', were placed in three distinct groups. We observed an obvious heterotic pattern in the studied flue-cured germplasm corresponding to genetic distances and classification dendrogram, which persuades exploitation of heterosis in flue-cured tobaccos.
\end{abstract}

Keywords: DNA polymorphism, effective allelic number, genetic variability, male sterile, molecular markers, UPGMA clustering method

\section{Introduction}

Nicotiana belongs to family Solanaceae and has been divided into three subgenera (Rustica, Tabacum and Petunioides) which contain more than 64 recognized species. Only two natural amphidiploid species, Nicotiana tabacum L. and Nicotiana rustica L. with $2 \mathrm{n}=48$ chromosomes (Raju et al., 2008) have widely been cultivated as a medicinal herb, trade commodity and as crop plant in many different cultures for thousands of years (Yang et al., 2007; Zhang and Liu, 2008). This plant is widely utilized as a model system in plant cell-cultures and genetic engineering researches (Zhang and Liu, 2008). Recently, use of tobacco seed oil as a renewable and potential source of energy was reported by authors (Giannelos et al., 2002). Because of its economic importance and value in biological researches, numerous investigations have been undertaken to examine its evolutionary origin and genome structure and organization (Zhang and Liu, 2008).

Numerous types of tobacco are defined by different criteria such as region of production, intended use in cigar (i.e., filler, binder and wrapper) and cigarette manu- facturing, method of curing (flue-, air-, sun- and fire-cured tobacco) as well as morphological and biochemical characteristics (i.e., aromatic fire-cured, bright leaf tobacco, Burley tobacco, Turkish or oriental tobacco) (Ren and Timko, 2001). Flue-cured tobacco (Nicotiana tabacum L.) is one of the most important commercial types of tobacco in the world (Liu et al., 2009) and uses as a main component in American Blend type cigarettes.

Tobacco breeding aims to develop varieties with wide adaptability, higher yield potential and suitable chemical constituents for cigarette industry. To explore the genetic potential and select suitable parents, it is necessary to study genetic diversity of tobacco germplasm (Yang et al., 2007). Characterization and quantification of genetic diversity has long been a major goal in tobacco breeding programs. Information on genetic diversity is essential for a rational use of genetic resources. Morphological, karyotypic, and physiological characters have already been used to study the genetic diversity of tobacco germplasm (Goodspeed, 1945; Zhang, 1994; Zhang et al., 2005). However, morphological characters usually vary with environments. The number of karyotypical characters is limited, and study of 
248

genotypic diversity based on isozyme variation is restricted to a few polymorphic enzyme systems encoded by a small number of loci (Zhang et al., 2006).

During the last two decades, DNA-based molecular markers have been extensively used for a variety of purposes in many animal and plant systems. DNA markers such as RFLP (Restriction Fragment Length Polymorphism; Botstein et al., 1980), RAPD (Random Amplified Polymorphic DNA; Williams et al., 1990), SSRs (Simple Sequence Repeats; Rafalski and Tingey, 1993), AFLP (Amplified Fragments Length Polymorphism; Vos et al., 1995), as well as SNP (Single Nucleotide Polymorphism; Haff and Smirnov, 1997) has accelerated and facilitated the genetic diversity and evolutionary studies in plants. Molecular markers have become useful tools to provide a relatively unbiased method of quantifying genetic diversity in plants. Studies on the genetic diversity were performed by several researchers in the genus Nicotiana using different molecular markers. Zhang et al. (2008) used RAPD and AFLP markers to assess the genetic similarity among selected flue-cured tobacco accessions. Arslan and Okumus (2006) studied the genetic polymorphism of cultivated tobaccos (Nicotiana tabacum L.) in Turkey by RAPD markers. Qi et al. (2006) used ISSR markers to study genetic diversity in Chinese tobacco germplasm and reported that the genetic basis was comparatively narrow in studied germplasm. The recent development of several hundred microsatellite markers for tobacco (Bindler et al., 2007) has opened the ways of analysing molecular genetic diversity in this crop. Microsatellite markers, mainly due to their high polymorphism, random distribution and co-dominant Mendelian inheritance, are the most reliable markers for cultivar identification and genetic diversity studies. They were applied in tobacco researches for identification of inbred lines and cultivars (Davalieva et al., 2010; Siva Raju, 2011). Davalieva et al. (2010) classified 10 tobacco genotypes into three groups using 24 SSR markers. SSR markers have been successfully employed to reveal genetic variation in chewing tobacco genotypes (Siva Raju, 2011). With the recent advent of high-density SSR maps for tobacco (Bindler et al., 2007), it is feasible to estimate genetic variation with a large number of SSR markers that are well distributed across the tobacco genome. The main advantage of using markers with known map positions is ability to create sufficient coverage over the genome. It is thus possible to avoid overrepresentation of certain regions of the genetic map that can produce inaccurate estimates of genetic similarities among individuals.

Iran, due to its geographical situation, is one of the most favourable regions for flue-cured tobacco cultivation. Little is known about the genetic variability of the available germplasm for flue-cured tobacco in Iran. The present study aimed to determine and assess the genetic variability of different local and exotic flue-cured tobacco using tobacco-specific simple sequence repeat (SSR) markers. This is the first report about the genetic diversity of flue-cured tobacco in Iran.

\section{Materials and methods}

\section{Plant material and DNA extraction}

Seventy-two flue-cured tobacco genotypes provided by Urmia Tobacco Research Center were investigated in the present study (Tab. 1). Seeds of genotypes were cultivated in pot and grown in growth chamber at $25 \pm 2^{\circ} \mathrm{C}$. Genomic DNA was extracted from the leaves of 50 -days-old seedlings using the CTAB-based method (Reichardt and Rogers, 1994). Genomic DNA was re-suspended in $100 \mu \mathrm{L} \mathrm{TE}$ (10 mM Tris, $1 \mathrm{mM}$ EDTA). The concentration of each DNA sample was determined spectrophotometrically at $260 \mathrm{~nm}$ (BioPhotometer 6131; Eppendorf, Hamburg, Germany). The quality of the DNA was checked by running $2 \mu \mathrm{l}$ DNA in $1 \%(\mathrm{w} / \mathrm{v})$ gels in $0.5 \mathrm{X}$ TBE buffer $(45$ $\mathrm{mM}$ Tris base, $45 \mathrm{mM}$ boric acid, $1 \mathrm{mM}$ EDTA pH 8.0). The DNA samples with smear in the gel were rejected.

Thirty SSR markers out of 278 from the tobacco SSR database (Blinder et al., 2007) were used for DNA fingerprinting (Tab. 2). The choice of SSR markers was based on clarity of produced bands and their genetic locations in order to give a uniform coverage of the tobacco genome (Blinder et al., 2007).

\section{Polymerase chain reaction (PCR)}

Amplifications were performed in a volume of $25 \mu \mathrm{l}$ containing $10 \mu \mathrm{M}$ of each primer, 0.5 unit of Taq DNA polymerase (CinnaGen, Tehran, Iran), $10 \mathrm{mM}$ of each dNTP (BioFluxbiotech, http://biofluxbiotech.com), $2 \mu \mathrm{l}$ of 10X PCR buffer, $50 \mathrm{mM} \mathrm{MgCl}$ (CinnaGen, Tehran, Iran), ddH2O and 50 ng DNA by using a 96-well Eppendorf Mastercycler Gradient (Type 5331, Eppendorf AG, Hamburg, Germany). Thermal cycles were programmed for 36 cycles as follows: $1 \mathrm{~min}$ at $94^{\circ} \mathrm{C}, 1.5 \mathrm{~min}$ at $55^{\circ} \mathrm{C}$, and $1.5 \mathrm{~min}$ at $72^{\circ} \mathrm{C}$, with an initial melting of $4 \mathrm{~min}$ at $94^{\circ} \mathrm{C}$, and a final extension of $10 \mathrm{~min}$ at $72^{\circ} \mathrm{C}$. The reaction products were mixed with $5 \mu \mathrm{l}$ of formamide dyes (98\% formamide, 10M m EDTA, 0.05\% bromophenol blue and $0.05 \%$ xylene cyanol) and resolved in a $3 \%(\mathrm{w} / \mathrm{v})$ agarose gel in $0.5 \mathrm{X} \mathrm{TBE}$ buffer, stained with $1.0 \mu \mathrm{g} \mathrm{ml}^{-1}$ ethidium bromide and photographed under UV light using a Gel-Doc image analysis system (Gel Logic 212 PRO, USA).

\section{Data analysis}

The amplification products were scored for the presence (1) and absence (0) of bands across the 72 genotypes to construct a binary data matrix. Mean number of allele per locus $\left(n_{a}\right)$, effective allele number $\left(n_{c}\right)$, allele frequency, observed and expected heterozygosities $\left(\mathrm{H}_{\mathrm{o}}\right.$ and $\mathrm{H}_{\mathrm{c}}$, respectively) were estimated using the GenAlEx software version 6.41 (Peakall and Smouse, 2006). $n_{a}=\sum_{i=1}^{n} n_{a i} / n$, where $n_{a}$ is the number of alleles at $\mathrm{i}^{\text {th }}$ locus. $n_{e}=\sum_{i=1}^{n} n_{e} i / n=\sum_{i=1}^{n}\left(1-\sum_{j=1}^{m_{i}} q_{i j}^{2}\right) / n$ (Brown and Weir, 1983), where $n_{e i}$ is the effective al- 
Tab. 1. Name of the flue cured tobacco genotypes and their special cluster group based on un-weighted pair-group method using arithmetic average (UPGMA) algorithm and Jaccard's similarity coefficient on simple sequence repeat data

\begin{tabular}{|c|c|c|c|c|c|c|c|c|}
\hline Code & $\begin{array}{c}\text { Flue-cured tobacco } \\
\text { genotype }\end{array}$ & $\begin{array}{l}\text { Cluster } \\
\text { group }\end{array}$ & Code & $\begin{array}{c}\text { Flue-cured tobacco } \\
\text { genotype }\end{array}$ & $\begin{array}{l}\text { Cluster } \\
\text { group }\end{array}$ & Code & $\begin{array}{c}\text { Flue-cured tobacco } \\
\text { genotype }\end{array}$ & $\begin{array}{l}\text { Cluster } \\
\text { group }\end{array}$ \\
\hline g1 & 'MontCalm Brum' & 1 & g25 & 'NC95 $\times$ Hicks' & 2 & g49 & 'MC101' & 2 \\
\hline $\mathrm{g} 2$ & 'Bell' & 2 & $\mathrm{~g} 26$ & 'K394' & 2 & $\mathrm{~g} 50$ & 'Vo3/15' & 2 \\
\hline g3 & 'PfaTzer' & 2 & $\mathrm{~g} 27$ & 'Kutsaga51E' & 2 & $\mathrm{~g} 51$ & 'NC11-15' & 2 \\
\hline g4 & 'Hawana142' & 2 & g28 & 'Bel71-500' & 2 & g52 & 'Coker258’ & 2 \\
\hline $\mathrm{g} 5$ & 'VirRee' & 4 & g29 & 'PBD6' & 2 & $\mathrm{~g} 53$ & 'Previ stammV3' & 2 \\
\hline g6 & 'Lassomption' & 2 & g30 & 'Vir63' & 2 & g5 54 & 'SpeightG28' & 2 \\
\hline g7 & 'Hawana' & 2 & g31 & 'Virree48' & 2 & g55 & 'VirEl' & 2 \\
\hline g8 & 'Petrich84' & 2 & g32 & 'Kutsaga513' & 2 & $\mathrm{~g} 56$ & 'Vo3/10' & 2 \\
\hline g9 & 'Vir53' & 2 & g33 & 'South Carolina' & 2 & $\mathrm{~g} 57$ & 'Tirtash19' & 2 \\
\hline g10 & 'Sumatra9' & 2 & g34 & 'Vo3/3' & 2 & $\mathrm{~g} 58$ & 'Bel61-9' & 2 \\
\hline g11 & 'Hicks' & 2 & g35 & 'Asombon' & 2 & g59 & 'Vir31' & 2 \\
\hline g12 & 'Bel61-10' & 4 & g36 & 'Kut110' & 2 & $\mathrm{~g} 60$ & 'Geaderthermer' & 2 \\
\hline g13 & 'RoseCanell' & 2 & g37 & 'Vir37’ & 2 & $\mathrm{~g} 61$ & 'El' & 2 \\
\hline g14 & 'AllPurpase' & 2 & g38 & 'FixedA1' & 2 & $\mathrm{~g} 62$ & 'Glustinusa Rasht' & 3 \\
\hline g15 & 'Parafum' & 2 & g39 & 'Vo3/4' & 2 & $\mathrm{~g} 63$ & 'Coker342' & 2 \\
\hline g16 & 'VirHerzegorina' & 4 & g40 & 'PeeDee' & 2 & g64 & 'Florida513' & 2 \\
\hline g17 & 'VirH-R' & 2 & g41 & 'Harrison' & 2 & g65 & 'Perega' & 2 \\
\hline g18 & 'ComSock Spanish' & 4 & g42 & 'By4' & 2 & g66 & 'Manilla' & 2 \\
\hline g19 & 'GewonGrone' & 2 & g43 & 'VirAurea' & 2 & $\mathrm{~g} 67$ & 'MC1' & 2 \\
\hline g20 & 'Ludoyoretz' & 4 & g44 & 'Virgold' & 2 & g68 & 'Coker176' & 2 \\
\hline g21 & 'NCTG52' & 4 & g45 & 'Amers' & 2 & g69 & 'VirAmutant' & 1 \\
\hline g22 & ‘Vir R.P37’ & 2 & g46 & $' \mathrm{Vo} 3 / 5$ & 2 & g70 & 'Vo3/11' & 2 \\
\hline g23 & 'NC95' & 2 & g47 & 'Coker55’ & 2 & g71 & 'Coker254' & 2 \\
\hline g24 & 'Hicks26-110' & 4 & $\mathrm{~g} 48$ & 'Coker319' & 2 & g72 & 'Vo3/6 & 2 \\
\hline
\end{tabular}

lelic number at $\mathrm{i}^{\text {th }}$ locus, and $q_{j}$ the frequency of the $j^{\text {th }}$ allele. Allele frequency $=\frac{2 N_{X X}+N_{X X}}{2 N}$, calculated locus by locus (Hartl and Clark, 1997); where $N_{X X}$ is the number of homozygotes for allele, $X(X X) N_{X Y}$ is the number of heterozygotes containing the allele $X$ ( $Y$ can be any other allele), $\mathrm{N}=$ the number of samples. $H_{o}=\sum_{i=1}^{n} H_{o i} / n=\sum_{i=1}^{n}\left(1-\sum_{j=1}^{m i} q_{i j}^{2}\right) / n \quad$ (Hartl and Clark, 1997), where $H_{o i}$ represents the observed heterozygosity of the $i^{t h}$ locus, and $q_{i j}$ is the frequency of the $j^{t h}$ allele at $i^{\text {th }}$ locus. $H_{e}=\sum_{i=1}^{n} H i / n=\sum_{i=1}^{n}\left(1-\sum_{j=1}^{m i} q_{i}^{2}\right) / n$ (Lynch and Milligan, 1994), where $H_{i}$ is the expected heterozygosity of the $i^{\text {th }}$ locus, and $q_{i j}$ is the frequency of the $j^{\text {th }}$ allele at $i^{\text {th }}$ locus. Different methods were used for calculating similarity matrices and constructing dendrograms. The efficiency-of-clustering algorithms and their goodness-of-fit were determined based on co-phenetic correlation coefficients. Data analyses were performed using the NTSYS-pc version 2.11 software (Rohlf, 1998).

\section{Results and discussion}

Out of 278 SSR primer pairs tested (Blinder et al., 2007), 30 primer pairs were selected according to their polymorphism (Tab. 2). One hundred and four alleles were generated at 30 SSR loci. The size of amplified PCR products ranged from 140 to $322 \mathrm{bp}$ (Tab. 2). Number of allele per locus ranged from 2 to 6 (PT30285 locus) suggesting the presence of high molecular genetic variability among the studied tobacco genotypes which are in agreement with the finding of Davalieva et al. (2010), Denduangboripant et al. (2010), and Moon et al. (2008; 2009) by means of SSR, AFLP and SSR markers, respectively. In the current study, the mean number of allele per locus was 3.46, which was similarly reported in Macedonian tobaccos with average of 3 alleles per locus (Davalieva et al., 2010). The effective allelic number $\left(\mathrm{n}_{\mathrm{e}}\right)$ was 2.36 on average and ranged from 1.398 to 4.01 . This parameter takes into account both the number of alleles and their frequencies. It allows us to compare genotypes where the number and distributions of alleles differ drastically. The observed heterozygosity ranged from 0.00 to 0.94 , with an average of 2.36 . Six loci did not show any heterozygosity. The expected heterozygosity ranged from 0.29 to 0.75 with average of 0.54 . The informativeness of SSR markers were measured by expected heterozygos- 
Tab. 2. Names, sequences and linkage groups of the 30 simple sequence repeat (SSR) primer pairs applied to 72 flue-cured tobacco genotypes

\begin{tabular}{|c|c|c|c|c|c|c|}
\hline $\begin{array}{c}\text { Primer } \\
\text { name }\end{array}$ & $\begin{array}{l}\text { Size } \\
\text { (bp) }\end{array}$ & Sequence of primer $\mathrm{F} 5^{\prime} \rightarrow 3^{\prime}$ & Sequence of primer R $5^{\prime} \rightarrow 3^{\prime}$ & $\begin{array}{c}\text { Repeated } \\
\text { motif }\end{array}$ & AT & LG \\
\hline PT30021 & 224 & CATTTGAACATGGTTGGCTG & CTCAACTCTCGTCGCTCTTG & TA & 55 & 4 \\
\hline PT30132 & 216 & CCTAACAGCATTTGCTACCCA & GATGGACAAGAGTGGCCTTT & TA & 55 & 10 \\
\hline PT30202 & 225 & TCGAAACCTCGAGGACAGTT & TATCCAAATCTCCAAAGCCC & GA & 55 & 7 \\
\hline РТ30159 & 197 & GCATGCATATGAACATGGGA & TTTGACATCTCTACTCTTCCGTTT & TA & 55 & $14 \mathrm{~b}$ \\
\hline PT30175 & 229 & TTAGGCGGCGGTATTCTTAT & TATGCCTCAATCCCTTACGC & TA & 55 & $14 \mathrm{a}$ \\
\hline PT30285 & 177 & CATCATGGCAAGTCACCATC & TGCTGGAAATTAGCGAGGTT & TA & 55 & 18 \\
\hline РТ30324 & 151 & TGCTCTGCGTTAGAACAGGA & CGACGAGAGAAGATTAGTGAAAGA & TAA & 55 & 12 \\
\hline PT20343 & 322 & GGAACACCACCACCATAA & GGAGCTCAGGTTCCAATG & $\mathrm{AC} / \mathrm{AG} / \mathrm{AT}$ & 55 & 4 \\
\hline РТ30075 & 195 & CGATCGGGTCGTTACACAAT & CCCATCAGGTTGTTGGGTTA & TA & 55 & 11 \\
\hline PT30241 & 199 & AAGTCTCGTGTGGTTGCTTT & AAAGGGCAATGTGTCTAGCTC & GA & 55 & 15 \\
\hline РT30061 & 182 & TCGTCCATTTCTTTCTCTCTCA & CATAAATAGTTGCTCATTCAATCG & TA & 55 & 11 \\
\hline PT30144 & 266 & TGATTTGTATTGACAGCGTGAAG & TTGTTTAGTTACCCTATTTGACTTGC & TA & 55 & 16 \\
\hline РT30332 & 230 & AAACCGAACCGAACTGATTT & TCAAATTTATGATTCTTGTAGCGAA & TA & 55 & 16 \\
\hline РТ30124 & 228 & TCСТССАACСAAACTCAAGC & TTTCTGTTCGCGTTTCAAAT & TA & 55 & 4 \\
\hline PT30110 & 213 & TTGTACGTTCCTCGCTGATG & GGCCGACAATAAAGTGGCT & TA & 55 & 21 \\
\hline PT20275 & 184 & GTTCTATTTGATCGCCCC & AACAGCACCAACAGCATT & CTT & 55 & 5 \\
\hline РТ30260 & 225 & GGTAGGGTGGAACAAATTTATCA & AATATGGTCTATGCCCGCAA & $\mathrm{TA}$ & 55 & $8 \mathrm{a}$ \\
\hline PT30067 & 204 & AAGCCTGGTCAGTTATCCCA & ATTCGCACCACTTAATCCCA & TA & 55 & 2 \\
\hline РT30126 & 208 & GTGATTCCAGCGGAAGACAT & TTCGAAATAAGTACCTAGAGTCGG & TA & 55 & 10 \\
\hline РT30034 & 216 & GACGAAACTGAGGATATTCCAAA & TGGAAACAAAGCCATTACCC & TAA & 55 & 22 \\
\hline РТ30008 & 192 & CGTTGCTTAGTCTCGCACTG & GGTTGATCCGACACTATTACGA & TA & 55 & 11 \\
\hline PT30165 & 224 & ACCTCTGTGGCCGTAAGCTA & ССТСТАСТTCAACAGGGTAAGAAA & TAA & 55 & 19 \\
\hline PT30014 & 205 & TGCCGTGTAAATTTCATTTGG & AGGATTCCTAACGTGTATTATGTTCT & TA & 55 & 11 \\
\hline PT30272 & 140 & GAACCTAACCTCGCTCCACA & AAATGGTAGCTGCGAGGAGA & GA & 55 & 4 \\
\hline РT30171 & 218 & CCCATGCATGCCTAATTTCT & CCCAGAAGCCСTTATACAACC & TA & 55 & 24 \\
\hline РT30172 & 216 & AAACAACGTCGAAGCATTTG & ACGCATGAAATTGTAAGGGC & GAA & 55 & 4 \\
\hline PT30205 & 193 & GGTCGATCCACAATTTAAACG & GCACTTGCTCCTTTGTACCC & TA & 55 & $3 b$ \\
\hline PT20287 & 164 & CGCCACAACAACTCACСТТА & TCATGCATGTTTCTCСTCСTT & AAG & 55 & $3 a$ \\
\hline РT30250 & 177 & GAACACACGTTCGTCATTGG & ATAAGTCCCTTTAATTTAATTGCG & TAG & 55 & 10 \\
\hline PT30292 & 156 & AAGACAGATTGGTGCGGAAC & AGCACTTGGACAGGCGAATA & TA & 55 & 7 \\
\hline
\end{tabular}

AT: Annealing temperature, LG: linkage group

ity. SSR markers with high heterozygosity values such as PT30126 and PT30285 could be effectively used in genetic diversity studies. There is a considerable difference between observed and expected heterozygosity for several analysed SSRs, indicating lack of Hardy-Weinberg equilibrium. This situation could be consequence of selection or gene flow or even the genetic drift. Wright fixation index (F) ranged from 0.00 (PT30202, PT30324, PT30285, PT30124, PT30205) to 1.00 (РT30241, PT30332, PT30110, PT20275, PT30171, and PT30250) with an average of 0.64 (Tab. 3).

Different methods were used to construct the similarity matrices and dendrograms (Tab. 4). The co-phenetic correlation coefficient, a measure of the correlation between the similarities represented on the dendrograms and the actual degree of similarity, was calculated for each dendrogram (Tab. 4). Among the different methods, the highest value $(r=0.76368)$ was observed for the UPGMA method based on Jaccard's similarity coefficients (Tab. 4).
Therefore, the dendrogram constructed using this method was used to depict the genetic diversity of the flue-cured tobacco genotypes (Fig. 1). The genetic similarity among the tobacco genotypes varied from 0.08 (between 'Geaderthermer' and 'Hawana 142' genotypes) to 0.84 (between 'MC101' and 'Vo3/15' genotypes) based on Jaccard's similarity coefficient, which indicates the high level of genetic variation among studied flue-cured tobacco genotypes. This result also validates that this collection is a valuable tobacco germplasm that has not been exposed to degradation yet. Davalieva et al. (2010) indicated a wide range of genetic diversity among the selected tobacco varieties using SSR markers. In a SSR marker study, it was demonstrated that the most of the US Nicotiana germplasm collection are considerably distinct from each other (Moon $e t$ al., 2009) that is in agreement with the present results. In contrast to the present results, Yang et al. (2007) by using inter-simple sequence repeat and inter-retrotransposon amplification polymorphism (IRAP) markers, Arsalan 
Tab. 3. Number of alleles $(\mathrm{Na})$, effective allelic number $(\mathrm{Ne})$, observed heterozygosity $(\mathrm{Ho})$ and expected heterozygosity (He) and allele frequency of the 30 simple sequence repeat (SSR) loci applied to 72 flue-cured tobacco genotypes

\begin{tabular}{|c|c|c|c|c|c|c|c|c|c|c|c|}
\hline \multirow{2}{*}{$\begin{array}{c}\text { Primer } \\
\text { name }\end{array}$} & \multirow{2}{*}{$\mathrm{Na}$} & \multirow{2}{*}{$\mathrm{Ne}$} & \multirow{2}{*}{ Ho } & \multirow{2}{*}{$\mathrm{He}$} & \multirow{2}{*}{$\mathrm{F}$} & \multicolumn{6}{|c|}{ Allel frequency } \\
\hline & & & & & & A & $\mathrm{B}$ & $\mathrm{C}$ & $\mathrm{D}$ & $\mathrm{E}$ & $\mathrm{F}$ \\
\hline РT30021 & 3 & 2.925 & 0.21 & 0.658 & 0.681 & 0.371 & 0.371 & 0.258 & - & - & - \\
\hline РТ30132 & 5 & 2.901 & 0.617 & 0.655 & 0.059 & 0.025 & 0.158 & 0.525 & 0.125 & 0.167 & - \\
\hline РТ30202 & 4 & 2.895 & 0.896 & 0.655 & 0 & 0.343 & 0.104 & 0.455 & 0.097 & - & - \\
\hline РТ30159 & 4 & 3.28 & 0.183 & 0.695 & 0.736 & 0.242 & 0.183 & 0.442 & 0.133 & - & - \\
\hline РТ30175 & 3 & 2.697 & 0.263 & 0.629 & 0.582 & 0.175 & 0.412 & 0.412 & - & - & - \\
\hline РT30285 & 6 & 4.012 & 0.91 & 0.751 & 0 & 0.03 & 0.119 & 0.284 & 0.299 & 0.254 & 0.015 \\
\hline РТ30324 & 4 & 2.949 & 0.871 & 0.661 & 0 & 0.114 & 0.221 & 0.5 & 0.164 & - & - \\
\hline PT20343 & 3 & 2.851 & 0.075 & 0.649 & 0.885 & 0.239 & 0.425 & 0.336 & - & - & - \\
\hline РT30075 & 5 & 3.296 & 0.329 & 0.697 & 0.528 & 0.086 & 0.071 & 0.421 & 0.321 & 0.1 & - \\
\hline РТ30241 & 2 & 1.958 & 0 & 0.489 & 1 & 0.574 & 0.426 & - & - & - & - \\
\hline РТ30061 & 4 & 1.718 & 0.058 & 0.418 & 0.861 & 0.051 & 0.072 & 0.746 & 0.13 & - & - \\
\hline РТ30144 & 3 & 1.833 & 0.17 & 0.454 & 0.626 & 0.179 & 0.708 & 0.113 & - & - & - \\
\hline РT30332 & 3 & 2.214 & 0 & 0.548 & 1 & 0.393 & 0.541 & 0.066 & - & - & - \\
\hline РТ30124 & 4 & 2.697 & 0.657 & 0.629 & 0 & 0.06 & 0.127 & 0.507 & 0.306 & - & - \\
\hline РТ30110 & 5 & 2.483 & 0 & 0.597 & 1 & 0.015 & 0.029 & 0.074 & 0.382 & 0.5 & - \\
\hline PT20275 & 2 & 1.6 & 0 & 0.375 & 1 & 0.75 & 0.25 & - & - & - & - \\
\hline РТ30260 & 3 & 1.443 & 0.083 & 0.307 & 0.729 & 0.083 & 0.094 & 0.823 & - & - & - \\
\hline РТ30067 & 4 & 2.786 & 0.069 & 0.641 & 0.892 & 0.017 & 0.302 & 0.207 & 0.474 & - & - \\
\hline РТ30126 & 4 & 3.551 & 0.078 & 0.718 & 0.891 & 0.324 & 0.157 & 0.353 & 0.167 & - & - \\
\hline РT30034 & 3 & 2.449 & 0.015 & 0.592 & 0.975 & 0.118 & 0.493 & 0.39 & - & - & - \\
\hline РТ30008 & 3 & 1.94 & 0.066 & 0.484 & 0.865 & 0.189 & 0.68 & 0.131 & - & - & - \\
\hline РТ30165 & 2 & 1.654 & 0.086 & 0.396 & 0.783 & 0.271 & 0.729 & - & - & - & - \\
\hline РТ30014 & 4 & 1.683 & 0.148 & 0.406 & 0.637 & 0.041 & 0.139 & 0.066 & 0.754 & - & - \\
\hline РТ30272 & 2 & 1.747 & 0.175 & 0.427 & 0.592 & 0.69 & 0.31 & - & - & - & - \\
\hline РТ30171 & 3 & 2.09 & 0 & 0.522 & 1 & 0.424 & 0.545 & 0.03 & - & - & - \\
\hline РТ30172 & 2 & 1.411 & 0.231 & 0.291 & 0.208 & 0.177 & 0.823 & - & - & - & - \\
\hline РT30205 & 4 & 2.318 & 0.939 & 0.569 & 0 & 0.015 & 0.068 & 0.402 & 0.515 & - & - \\
\hline РT20287 & 2 & 1.398 & 0.031 & 0.285 & 0.89 & 0.172 & 0.828 & - & - & - & - \\
\hline РТ30250 & 3 & 1.574 & 0 & 0.365 & 1 & 0.042 & 0.775 & 0.183 & - & - & - \\
\hline РТ30292 & 5 & 2.383 & 0.092 & 0.58 & 0.841 & 0.031 & 0.069 & 0.177 & 0.608 & 0.115 & - \\
\hline Mean & 3.467 & 2.358 & 0.242 & 0.538 & 0.642 & & & & & & \\
\hline
\end{tabular}

and Okumus (2006) using RAPD markers and Ren and ences in results reported by various studies could be due to Timko (2001) using AFLP markers reported the low lev- differences in number of studied genotypes, their genetic els of genetic diversity among Chinese flue-cured tobacco background, and number of markers used as well as techcollections, cultivars planted in eastern Anatolia of Turkey niques applied to detect polymorphism. and some world tobacco collection, respectively. Differ-

Tab. 4. Comparison of different methods for constructing similarity matrices and dendrograms in 72 flue-cured tobacco genotypes

\begin{tabular}{ccc}
\hline Similarity matrices & Algorithm & Co-phenetic coefficient \\
\hline Jaccard & UPGMA & 0.76368 \\
Jaccard & Complete linkage & 0.56817 \\
Jaccard & Single linkage & 0.71573 \\
Dice (Nie and Li) & UPGMA & 0.74314 \\
Dice (Nie and Li) & Complete linkage & 0.5381 \\
Dice (Nie and Li) & Single linkage & 0.71897 \\
Simple matching & UPGMA & 0.74279 \\
Simple matching & Complete linkage & 0.57483 \\
Simple matching & Single linkage & 0.70047 \\
\hline
\end{tabular}

UPGMA = un-weighted pair-group method using arithmetic average 


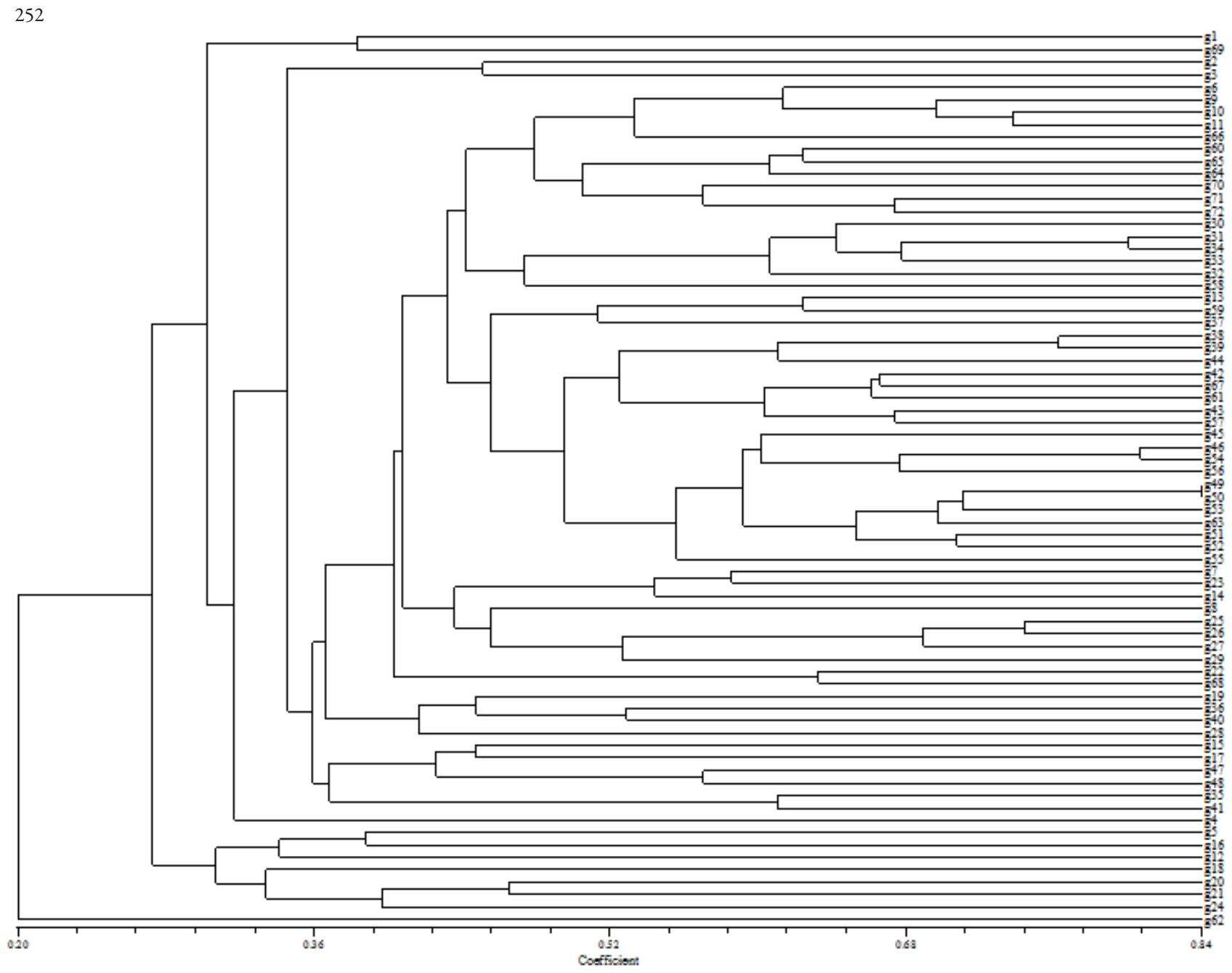

Fig. 1. Dendrogram of 72 flue-cured tobacco genotypes generated by un-weighted pair-group method using arithmetic average (UPGMA) clustering based on Jaccard's coefficients of similarity on the simple sequence repeat (SSR) data

Based on UPGMA clustering method the studied flue-cured tobacco genotypes, except for genotype 'Glustinusa Rasht' were separated into three distinct groups. The majority of genotypes clustered in group 2. Seven male sterile genotypes ('Vo3/3', 'Vo3/4', 'Vo3/5', 'Vo3/6', 'Vo3/10', 'Vo3/11', and 'Vo3/15') were included in the present study as well. They all displayed a similar DNA fingerprint. These genotypes situated in group 2 . The genotype 'Vo3/15' showed high genetic similarity (0.84) with 'MC101' genotype. Genotype 'Vo3/3' showed low similarity (0.38) to 'Virree48'. Genotype 'Vo3/4' located in the same sub-cluster with 'FixedA1' genotype. Other male sterile genotypes ('Vo3/11', 'Vo3/6', and 'Vo3/10') located near to each other in cluster 2. Male sterile lines persuade the application of line $\times$ tester design in fluecured tobacco breeding programs. In this study, genotype 'Glustinusa Rasht' was placed into a separate cluster, emphasizing the existence of high level of difference between this genotype and others. Regarding to genetic distances and classification dendrogram, there is obvious heterotic pattern in this flue-cured germplasm which persuade exploitation of heterosis in flue-cured tobaccos. Duplica- tions of genetic material were not observed in the studied germplasm collection.

\section{Conclusions}

Identification and quantification of genetic diversity has long been a major aim in plant breeding programs. Information on genetic diversity is essential for use of genetic resources in breeding programs. It is especially useful in characterizing individual, accessions and cultivars as well as in detecting duplications of genetic material in germplasm collections. As a consequence, it is important to select appropriate parents for hybridization in breeding programs and in developing informative mapping populations for QTL identification. Hybridization between any distantly related individuals is expected to yield more heterosis and vigorous plants constituting much of the different traits contained in the two parental lines. The present study shows that development of SSR markers is a valuable issue for genetic diversity studies within the genus Nicotiana. 


\section{Acknowledgments}

We would like to thank the Institute of Biotechnology, Urmia University, Urmia, Iran, and Urmia Tobacco Research Center for financial support of this work.

\section{References}

Arslan B, Okumus A (2006). Genetic and geographic polymorphism of cultivated tobacco (Nicotiana tabacum) in Turkey. Russ J Genetics 42:667-671.

Bindler G, van der Hoeven R, Gunduz I, Plieske J, Ganal M, Rossi L, Gadani F, Donini P (2007). A microsatellite marker based linkage map of tobacco. Theor Appl Genetics 114:341-349.

Botstein D, White RL, Skolnick M, Davis RE (1980). Construction of a genetic linkage map in man using restriction fragment length polymorphisms. Am J Human Genetic 32:314-331.

Brown AHD, Weir BS (1983). Measuring genetic variability in plant populations, 219-239 p. In: Tanksley SD, Orton L (Eds.). Isozymes in plant genetics and breeding, Part A. Elsevier Science Publishers BV, Amsterdam.

Davalieva K, Maleva I, Filiposki K, spiroski O, Efremov GD (2010). Genetic variability of Macedonian tobacco varieties determined by microsatellite marker analysis. Diversity 2:439-449.

Denduangboripant J, Piteekan T, Nantharat M (2010). Genetic polymorphism between tobacco cultivar-groups revealed by amplified fragment length polymorphism analysis. J Agric Sci 2:41-48

Giannelos PN, Zannikos F, Stournas S, Lois E, Anastopoulos G (2002). Tobacco seed oil as an alternative diesel fuel: physical and chemical properties. Ind Crops Prod 16:1-9.

Goodspeed TH (1945). Chromosome number and morphology in Nicotiana. VII. Karyotypes of fifty-five species in relation to a taxonomic revision of the genus. Univ California Pub in Bot 18:345-370.

Haff LA, Smirnov IP (1997). Single-nucleotide polymorphism identification assays using a thermostable DNA polymerase and delayed extraction MALDI-TOF mass spectroscopy. Genome Res 7:378-388.

Hartl DL, Clark AG (1997). Principles of Population Genetics, $3^{\text {rd }}$ Ed. Sunderland, Massachusetts: Sinauer Associates, 542 p.

Liu XZ, Shen HeC, Yang YM, Zhang H (2009). Genetic diversity among flue-cured tobacco cultivars on the basis of AFLP markers. Czech J Genetics Plant Breed 4:155-159.

Lynch M, Milligan BG (1994). Analysis of population genetic structure with RAPD markers. Molec Ecol 3:91-99.

Moon HS, Nicholson JS, Lewis RS (2008). Use of transferable Nicotiana tabacum L. microsatellite markers for investigating genetic diversity in the genus Nicotiana. Genome 51:547559.

Moon HS, Nifong JM, Nicholson JS, Heineman A, Lion K, van der Hoeven R, Hayes AJ, Lewis RS (2009). Microsatellitebased analysis of tobacco (Nicotiana tabacum L.). Genetic resources. Crop Sci 49:2149-2159.

Peakall R, Smouse PE (2006). GENALEX 6: genetic analysis in Excel. Population genetic software for teaching and research. Molec Ecol Notes 6:288-295.

Qi JM, Wang T, Chen SH, Zhou DX, Fang PP, Tao AF, Liang JX, Wu WR (2006). Genetic diversity and genetic relatives analysis of tobacco germplasm based on inter-simple sequence repeat (ISSR). Acta Agron Sinica 32:373-378.

Rafalski JA, Tingey SV (1993). Genetic diagnostics in plant breeding: RAPDs, microsatellites and machines. Trends Genet 9:275-279.

Raju KS, Madhav MS, Sharma RK, Murthy TGK, Mohapatra $\mathrm{T}$ (2008). Genetic polymorphism of Indian tobacco types as revealed by amplified fragment length polymorphism. Current Sci 94:633-639.

Ren N, Timko MP (2001). AFLP analysis of genetic polymorphism and evolutionary relationships among cultivated and wild Nicotiana species. Genome 44:559-571.

Rohlf FJ (1998). NTSYSpc: Numerical Taxonomy and Multivariate Analysis System version 2.02, Exeter Software, Setauket, NY.

Reichardt M, Rogers S (1994). Preparation of plant DNA using CTAB, 2.3.3-2.3.7 p. In: Ausubel F, Brent R, Kingston RE, Moore DD, Seidman JG, Smith JA, Struhl K (Eds.). Current Protocols in Molecular Biology, John Wiley \& Sons, NY.

Siva Raju K (2011). Genetic diversity in Indian chewing tobacco (Nicotiana tabacum) as revealed by RAPD and SSR markers. The Ind J Agric Sci 81:15-19.

Vos P, Hogers R, Bleeker R, Reijans M, Van DE, Lee T, Hornes $M$ (1995). AFLP: a new technique for DNA fingerprinting. Nucleic Acids Res 23:4407-4414.

Williams JGK, Kubelik AR, Livak KJ, Rafalski JI, Tingey SV (1990). DNA polymorphism amplified by arbitrary primers are useful as genetic markers. Nucl Acids Res 18:65316535.

Yang BC, Xiao BG, Chen XJ, Shi CH (2007). Assessing the genetic diversity of tobacco germplasm using inter-simple sequence repeat and inter-retrotransposon amplification polymorphism markers. Ann Appl Biol 150:393-401.

Zhang HY, Liu XZ (2008). Advance of molecular marker application in the tobacco research. Afr J Biotechnol 7:48274831.

Zhang HY, Liu XZ, Sheng HeC, Yang YM (2008). Genetic diversity among flue-cured tobacco cultivars based on RAPD and AFLP markers. Braz Arch Biol Technol 6:10971101.

Zhang HY, Liu XZ, Li TS, Yang YM (2006). Genetic diversity among flue-cured tobacco (Nicotiana tabacum L.) revealed by amplified fragment length polymorphism. Molec Biol 47:223-229.

Zhang HY, Liu XZ, He CS, Zheng CM (2005). Random amplified DNA polymorphism of nicotiana tabacum L. cultivars. Biol Plant 49:605-607.

Zhang DM (1994). Study on surface structure scanning of some tobacco seeds with electrical-glass observing. Chinese Tobacco Sinica 2:12-15 (In Chinese). 